\title{
The Upshot of Key Words Technique: Descriptive Writing of English Learners
}

\author{
Andi Sadapotto ${ }^{1}$, Nicodemus Bisse ${ }^{2}$ \\ ${ }^{1}$ English Education Departement \\ Universitas Muhammadiyah SidenrengRappang, Indonesia \\ ${ }^{2}$ English Education Departement \\ Universitas Cendrawasi, Indonesia.
}

*Corresponding Author. E-mail: sadapotto.andi@yahoo.co.id, nikobais56@gmail.com

Receive: 06/01/2021

Accepted: 08/02/2021

Published: 09/03/2021

\begin{abstract}
Abstrak
The objective of this article is to describe the upshot students descriptive writing at eleventh grade in SMA Muhammadiyah Rappang. This research employed the method of the research was pre-experimental method with one group pre-test and post-test design. The population was the Eleventh grade students (XI) of SMA Muhammadiyah Rappang in 2015-2016 academic years. Totalnumber of population was 20 students and the sample was taken by using census sampling technique, whole students at eleventh grade (20) was chosen as a sample. The instrument used in this research was to write decriptive composition. The result of this research showed that the pre-test got the mean score (53.60) while the post-test got mean score (77.95). This showed that there was significant difference between pre test and post-test. The result of the p-value (0.00) was lower than alpha (0.05). This means that $\mathrm{H}_{1}$ was accepted . the reserch concluded that teaching writing by using keyword increased the students' ability to write descriptive composition at eleventh grade in SMA Muhammadiyah Rappang.
\end{abstract}

Keywords: Deskriptif Writing; English Learners 


\section{INTRODUCTION}

English is considered as a difficult subject for the Indonesian students, because English is completely different from Indonesian language being looked at from the system of structure, pronunciation and vocabulary. It concerns with students ability in expressing their ideas, thoughts, and feelings through written form. We know that there are two kinds of language which are oral language and written language, on this proposal the researcher will observe about written language.

There are four kind skill in English, Speaking, Reading, Listening, and Writing. Writing is an important skill. It is always done in the classroom. Charles F. Meyer (2009:83) stated that written language is different with oral language, writing is more distant than speaking, writing needs of the audience to whom the writing is directed have to be anticipated by the writer, and once the reader receives the text there is no way for him or her to engage with the author if something is not clear.

In term written language has more benefit that spoken language in communicating ideas, students can learn much from writing. Statement above explain about writing done often in school as a way to achieve English Proficiency. According to Judith F. Oslon (2009:2) also stated that writing has three distinct advantages over speaking:

a. in writing, you can take it back. The spoken word, however, cannot be revised. Once you make a statement verbally, it affects your listeners in a particular way, and you can't "take it back" or rephrase it to the point that the first statement is forgotten. However, if you write a statement and, after looking at it, realize that it sounds offensive or incorrect, you can revise it before giving it to the intended audience. Writing is a careful, thoughtful way of communicating;

b. writing forces you to clarify your thoughts. If you're having trouble writing, it's often because you're not yet finished with the thinking part. Sometimes, just sitting down and writing whatever is on your mind helps you discover and organize what you think;

c. another advantage is permanence. Ideas presented in writing carry far more weight than spoken ideas. Additionally, they can be reviewed and referred to in their exact, original form. Spoken ideas rely upon the sometimes inaccurate memories of other people.

Many ways have been used by the teacher in teaching writing especially in descriptive composition. However sometimes he/she does not much attention to the students' interest in and purpose of writing. Sometimes students write only for assignment purpose not for communicative purposes. This indicates that students are not interest in their writing. One type of writing that sometimes makes the students difficult to compose the topic is descriptive writing.

In general, the students should have high ability in create writing. However, the fact reveals differently. There is a gap between fact and expectation. Many students still find writing as a difficult subject. They face some difficulties in writing.

Writing sounds simple, start with an attention-grabbing first sentence, then move on to some really interesting stuff in the middle, and then bring it all together at the end. The trouble is, how do we think up that attention-grabbing first sentence? Where do we go to find that really interesting stuff? What do we do if our mind is as blank as the paper you're staring at ? (Kate Grenville, 2001:6).

The difficulties of writing have been clearly explained by Byrne (1990:24). He states that there are three problems in writing. They are psychological, linguistic, and cognitive problems. For psychological problems, writing is considered as a solitary activity. We are required to wrote on our own without the possibility of interaction or the benefit of feedback. For linguistic problems, we have to keep the channel of communication. They refer to sentence structure and the way of sentences is linked together. For cognitive problems, we have to learn how to organize our ideas in such a way that they can be understood by a reader who is not present and perhaps by a reader who is not 
known to us. It deals with mastering written form of the English language. We cannot deny the three problems sometimes are overlap to some extends.

Realizing many problems are faced by our students in English teaching, we always try to find out how we can teach the English as foreign in the best way. As we know that there is no one method in the world that can be applied at the same time and place. The method will depend on what approach the teacher is pursuing, how we design our language teaching course, and what procedures we take to accomplish our objectives (Sainu, 1998:19).

The Keyword technique is an effective system for remembering definitions, learning foreign language vocabulary, and more. Any two pieces of information can be linked together in your memory using this method (Robert :2004). Keyword is a word that is closely linked to, or describes or defines, a particular subject.

Based on the statements above the researcher tried to find technique to help students if they face the situation above, In particular descriptive writing. And the researcher interesting in conducting a research on the title "The effect of key words technique to improve student's descriptive writing at the Eleventh grade students of SMA MuhammadiyahRappang".

\section{Literature Review}

\section{Previous Related Findings}

The first previous research was done by Sintawati (2012) entitled "Learning write narative by using clustering method to students of SMPN 1 Tanggeung Kab. Cianjur ". he finds out "Since the use of clustering method was applied in the teaching and learning process to learn, the interest of them in writing a foreign language increased, they gave good responds, activeness in the class and good achievement of the study that these all had been discussed in this study".

Masni Santung (2011). She found out that "Improving writing skill by using writing process approach at the second grade (TKJ department) students of SMK Nasional Makassar was very helps students to improve their effectiveness in writing skill".
Kasman (2003) in his research on using reading technique teaching to improve the writing ability of SLTP students finds that based on the data there was a significant difference between pre-test and post-test. It means that retekhnikl teaching was effective to improve the students writing descriptive composition.

Awaluddin (2006: 37) conducted a research on improving writing skill on the second year students of SMP Negeri 1 Duampanua Kabupaten Pinrang by using spider web.

\section{Writing}

\section{a. Definition of writing}

Writing is a complex activity. As you think about a topic you are already beginning to select words and construct sentences-in other words, to draft. As you draft and as you revise, the thinking goes on: you discover new ideas, realize you've gone down a dead end,discover an implication you hadn't seen before (Thomas $\mathrm{S}$. Kane,2000). Marrie Allen and Paul Procter (2008) stated that writing is to make marks which represent letters, words or numbers on a surface, such as papers or computer screen, using a pen, pencil or a keyboard or to use this method to record thoughts, facts or messages. It involves an active process to organize and formulate the ideas on the paper so that the reader can follow the writer's message as well as in oral form. But we should know that writing requires an accurate and practical grammar, word choice and spelling, punctuation and vocabulary.

Jack C. Richard and Willy A. Renandia (2002) said that the writing process as a private activity may be broadly seen as comprising foue stages planning, drafting, revising and editing.

According to Judith F. Oslon (2009:3) stated that Writing is nothing more than thought on paper-considered, organized thought. Many people are protective of their thoughts and, therefore, prefer to keep them hidden inside their heads. Writing encourages thinking and learning for it motivates communication and makes thought available for reflection. When thought is written down, ideas can be examined, reconsidered, added to, rearranged, and changed. In writing, a writer will be involved in the process of building the large units of ideas 
from smaller one. They will be linked to form sentence. The sentence will also be linked to form a piece of composition. Iryani (1998:6) said that writing means produce or reproduce message into written language. It involves an active process to organize and formulate the ideas on the paper so that the reader can follow the researcher's message as well as in oral form. But we should know that writing requires an accurate and practical grammar, word choice and spelling, punctuation and vocabulary. As one of the language skills, writing is used to express ideas. Ghaith (2002) said that writing is a complex process that allows researchers to explore thoughts and ideas, and make them visible and concrete. Writing encourages thinking and learning for it motivates communication and makes thought available for reflection. When thought is written down, ideas can be examined, reconsidered, added to, rearranged, and changed. In writing, a researcher was being involved in the process of building the large units of ideas from smaller one. They was being linked to form sentence. The sentence will also be linked to form a piece of composition.

Byrne (1984:1) stated that writing is clearly much more than the produce of graphic symbol as speech is more than the produce of sounds. The symbols have been arranged according to certain conventions, to form words, and words have to be arranged to form sentence. The essence of writing is a composing to give a form what we though, felt in word sequences, particularly the words have been written and arranged well that can be understand and easy to get the advantages by people who have read it. Thus, the researchers pour off what they though with engaging readers' attention. In connection with this, writing is a combination between process and product. The process is a timing to collect the data until readers can read the writing that is produced from the researchers' activities while the product is a purpose of the author and also the reason of process of pre-write, draft revision, and editing phase (Brown, 2001:335). By following these steps, the students are expected to produce the text quality.

Based on explanation above researcher concludes that Writing is defined as a group of letters or symbols written or marked on a surface as a means of communicating ideas for the purpose of recording the ideas which characters and words express, or of communicating them to others by visible signs. Writing is a method of representing language in visual or tactile form. Writing systems use sets of symbols to represent the sounds of speech, and may also have symbols for such things as punctuation and numerals.

\section{b. Function of writing.}

The function of writing according to Thulis Dawes (2009:3) stated that there are three functions of writing, which are :

1. Entertain, it doesn't necessarily make the readers laugh, but it at least engages their feelings emotionally in some way while they read the read a good reading material which is give. Think what it is like to be a good reader-you can be entertained (emotionally gripped) by something very serious, even sad, as well as by something funny. An exciting plot can involve your emotions, too, by creating feelings of suspense. Writing that involves emotions can also be reflective and contemplative. Writing to entertain generally takes the form of so-called imaginative writing' or 'creative writing' (of course, all writing requires some imagination and creativity). Examples of imaginative writing are novels, stories, poems, song lyrics, plays and screenplays. Sometimes imaginative writing disguises itself as a 'true story' for added effect. For example, The Secret Diary of Adrian Mole by Sue by Gary Crew and Libby Hathorn disguises itself as letters. As readers, though, we know that they're not really journals or letters-these are just devices the researcher has used to make the writing more entertaining;

2. inform, it tells the reader about something. These kinds of writing can also be 'entertaining' in the sense that they're a good read. But entertaining the reader isn't their main purpose-that's just a bonus. 
Examples of writing to inform are newspaper articles, scientific or business reports, instructions or procedures, and essays for school and university;

3. persuade, it tries to convince the reader about something. This includes advertisements, some newspaper and magazine articles, and some types of essay. This type of writing might include your opinion, but as part of a logical case backed up with evidence, rather than just as an expression of your feelings. I mentioned above that imaginative writing occasionally pretends to be a true story, but if you're writing to inform or persuade, you shouldn't make things up.

Based on the opinion above, the researcher concludes that writing is a kind of activity where the researcher expresses the ideas in his/her mind, thinking, and feelings in the form of words to sentences, sentences to paragraph, and from paragraph to essay. A researcher has to have ability in writing by using language patterns by written notice to express an idea and a message. The ability of writing means can understand what was being communicated, used in language patterns, organized in composing form, and also about used in diction correctly.

\section{c. Writing skill}

Writing skill is complex activity and also writing is considered as one of difficult to teach since it does not only mean to put down a graphic from a piece of paper. Writing is a social act in which it can be the best way to communicate our ideas to each other. Using writing skills can give a good attraction and improvisation to convey the real massages to the readers in the real life. In this connection, there are many linguists of conducting a research of writing have strengthen an they also explained several characteristics of well donewriting and suggestions to make a good writing. Bacon (1998: 11) postulates five professional rules for success in writing process, such as:

1. before writing, identify your purpose and stick to it;
2. identify your reader(s) in mind, make your message personal;

3. use language people understand;

4. organize first, and work from written outline;

5. finally, edit, revise, and rewrite your composition.

Writing is a communication process means of passing your advice, your knowledge, your thought and ideas, your stories to others. For the communication, to be completed you need a reader and the reader must get the message. In order to produce a good composition, it is primary necessary to acknowledge some basic principles of effective writing (Wells, 1993).

1. Write for yourself.

2. Write clearly for easy understanding.

3. Never try to impress the reader with your own cleverness or skill.

4. Capture the reader's interest quickly and relation throughout.

You have got make the readers want to read what to write by capturing the reader's interest. There are some ways also to strengthen the writing skills as follows:

1. read and write frequently. Read as much as you can from a variety of sources, including plays, essays, fiction, poetries, news stories, business writing and magazine features;

2. practice writing in different formats and in as many real situations as possible. Writing emails is good practice, but realize that writing for school and business is usually more formal than an email to a friend;

3. share your writing with others and get feedback. Feedback helps you to anticipate how readers may interpret your writing and what types of questions they may have. This stage can help you anticipate what the readers want to know;

4. become familiar with current issues in society and develop your own opinions on the issues. convince someone with your 
opinion and argument well. taking speech and debate classes can help you think through issues and communicate them to others;

5. try some extracurricular of writing such as school newspapers, yearbooks, and creative writing clubs offer opportunities to express ideas in writing;

6. learn to see writing as a processing, brainstorming, planning, writing and then editing. those apply on all writing activities;

7. listen to the advice of English teacher and lecturer that had been given in teaching of writing;

8. in writing try to be well-developed and wellorganized, using precise, clear and concise language;

9. remember that everyone can improve writing skills. confidence and skill will grow with the more writing you do. practice and work lead to get achievement.

In relation with the previous explanation, we can conclude that in making a good writing, there are many things that we have to consider if we want to write something.

\section{d. Writing process}

Most teachers divide the process of into three stages namely prewriting, writing, and revising. In prewriting, you think about your subject and purpose and organize those thoughts onto paper. At the end of the prewriting stage, you should know what you want to say and how you want to organize your points. During the writing stage, you put down those points, including a brief introduction and conclusion. After you've finished writing, you should have some time left for revising. In this stage, you read your essay to see if it covered the basic points thoroughly, provided good support, gave the reader a sense of direction or organization, and avoided grammatical errors.

Zuzanne Bratcher and lynda Ryan. 2004. divide the process of into Prewriting happens before a rough draft ever occurs. It includes brainstorming,discussions, drawing, dramatization, listening, reading, observing,researching, selecting a topic, and identifying the context of the writing. Most theorists agree that well over 50 percent of writing time is devoted to someform of prewriting.

Drafting begins when pencil hits paper and sentences begin to be composed.It includes freewriting, reading what has been written, and decidingwhat to do next.Revising occurs when a writer rereads a draft for ideas. Content and structureconcerns are addressed in the revising stage, most often with the help ofpeer readers. Editing focuses on sentence structure, word choice, and usage and mechanics. Most often it includes both attempts;/qat self-editing and the help of an outsideeditor. Once editing is complete, the student generally rewrites and proofreadsthe final draft for mistakes in copying. Publishing results in sharing the final draft. Teachers provide many differentways to publish student work: by displaying it on a bulletin board, by bindingit into a class book, by printing it in a newsletter, by entering it in a contest, by sending it home to parents, by giving it as a gift, by sharing it in adhocgroups, by reading it to the whole class from an author's chair, and so forth.

Most teachers divide the process of into three stages namely prewriting, writing, and revising. In prewriting, you think about your subject and purpose and organize those thoughts onto paper. At the end of the prewriting stage, you should know what you want to say and how you want to organize your points. During the writing stage, you put down those points, including a brief introduction and conclusion. After you've finished writing, you should have some time left for revising. In this stage, you read your essay to see if it covered the basic points thoroughly, provided good support, gave the reader a sense of direction or organization, and avoided grammatical errors. the strategies, procedures and decision-making employed by writers as they write. Writing is viewed as the result of complex processes of planning, drafting, reviewing and revising and some approaches to the teaching of first and second language writing teach students to use these processes (Jack C. Richardc and Richard 
Schmidt, 2002:592). In teaching composition an activity in which the teacher and a student meet for a short period of time to discuss student writing and different aspects of the composing process. Through regular conferences with students during a writing programme either in a part of the classroom or elsewhere, the teacher tries to promote awareness of writing strategies, to personalize writing for the student, and to make learners more confident about their writing.

Jack C. Richardc and Richard Schmidt (2002:592) state that writing process is the strategies, procedures and decision-making employed by writers as they write. Thomas $\mathrm{S}$. Kane (2000) stated that Writing in its broad sense as distinct from simply putting words on paper, and it has three steps; thinking about it, doing it and doing it again again and again, as often as time will allow and patience will endure. Simard (1997) also categorized the stages of writing into four steps of the writing process namely pre-writing, writing, re-writing, and post-writing.

\section{e. Components of writing.}

Jacob, et. al. (in Hughes, 2008:103) point out that in analytic scale, it has five components in writing. They are content, organization, vocabulary, language use and mechanics. A fifth component of writing is the process used by the writer to produce the product. While the sophistication of the activities writers carry out at each point in the process varies as students get older and more experienced, the components of the process remain the same.

\section{f. Writing Assignment}

Sometimes you're free to write whatever you like, but at school or university you will generally be given a specific writing assignment. This could be an imaginative writing assignment, an essay, or some other kind of writing task. Decoding the words of the assignment so that you give your teacher or lecturer exactly what he or she wants is part of your job as a researcher. According to Kate Grenvile $(2001 ; 5)$ stated that there are two clues embedded in every assignment that will help you crack the code.

1. The task word
The task word is usually the verb in the assignment-the word that tells you what to do. It might be something like: 'discuss'; 'descriptive'; 'write about'; or 'compare'. For example Write about your childhood.

2. The limiting word.

The limiting word (or words) narrows the assignment in some way. For example: Write about the most embarrassing incident of your childhood. Based on Theresa Clementon $(2005 ; 21)$ states that there are two kinds of writing assignment, which are ;
a. Imaginative writing,
b. Essay writing.

\section{Modes of writing}

Jack C. Richardc and Richard Schmidt (2002:337) state that non-creative forms of writing, particularly essay writing, have traditionally been classified into four types.

a. Descriptive writing provides a verbal picture or account of a person, place or thing.

b. Narrative writing reports an event or tells the story of something thathappened.

c. Expository writingprovides information about and explains a particula subject. Patterns of development within expository writing includegiving examples, describing a process of doing or making something, analyzing causes and effects, comparing and/or contrasting, defining aterm or concept, and dividing something into parts or classifying it intocategories.

d. Argumentative writing attempts to support a controversial point ordefend a position on which there is a difference of opinion, ESLwriting programmes have often been based on the assumption thatnovice writers should begin with the simplest mode - the descriptiveessay, and gradually move to learning the most difficult - the argumentative one. 


\section{Descriptive Text}

a. Definition of descriptive text

Descriptive text reproduces the way thing looks, smell, taste, feel, or sound; it may also evoke moods such as happiness, loneliness, or fear. It is used to create visual image of people, places, or season, it develop an aspect of their work, e.g. to create a particular mood, atmosphere or describe a place so that the reader can create vivid pictures of characters, places, objects or event. W. Rotter and H. Bendl (1978: 91102)states that descriptive text is a text which say what a person or a thing is like. Its purpose is to describe and reveal a particular person, place, or thing.

\section{b. The General structure of descriptivetext}

On this research was focussed in descriptive writing which explained before that the purpose of descriptive text is to describe a particular person, thing, animal or place. In descriptive writing inthis research researcher will the generic structure which are introduction, body, and closing (James Heard, M. Ed. And Ted Tucker, M. Ed, 2013:73)

\section{Keyword}

\section{a. The concept of keyword}

a. Creme and Lea (2003) stated that keyword your ideas in writing is that you simply note down as many ideas as possible about a topic, in words.

b. Evans (2000) stated that keyword is a technique to stimulate students knowledge about the topic, thus drawing together ideas and vocabulary which is necessary for writing a successful composition.

c. Heard and Tucker (2013) stated that keyword is the technique of listing any and all ideas that occur to the writer about a topic.

d. Richardc and Schmidt (2002:58) stated about keyword :
1. (in language teaching) a group activity in which learners have a free and relatively unstructured discussion on an assigned topic as a way of generatingideas. keywordoften serves preparation for another activity.

2. (in teaching writing) a form of prewriting inwhich a student or group of students write down as many thoughts aspossible on a topic without paying attention to organization, sentence structure or spelling. keywordserves to gather ideas, viewpoints, orideas related to awriting topic and is said to help the writer produce ideas.

\section{b. Fundamental keyword principle}

These principles form the basis of the two keywordtechniques used in this research project.

a) Keywordis designed to facilitate lateral thinking. This in turn is based on the premise that the human brain is a pattern recognition machine. Humans interact with their real environment in patterned ways and it can sometimes be difficult to move beyond these patterns and develop creative solutions to problems. The techniques used in this research project aim to disrupt these patterned ways of thinking and facilitate a more lateral approach to dealing with a writing question.

b) Individual keywordhas generally been found to yield a greater quantity and variety of ideas. This is because group situations tend to allow people with more forceful and confident personalities to dominate discussion. It has also been found that in group situations, as soon as the first idea has been presented, the rest of the group immediately begin to modify and censor their own ideas. Beginning a keywordsession by allowing students some time to think about and respond to a question individually yields a richer variety of ideas and encourages all students to actively participate. 
c) Effective keywordrequires a free flowing of ideas. It is therefore important that all ideas are welcomed, and nothing is criticised or rejected during a keywordsession as this may stifle creativity and lower student confidence and engagement.

\section{c. How to use keyword}

One effective way to get started is ask the big questions about your subject that you will going to compose and then ignite some questions of yourselve ; Who ? What? Where? When? Why? How? And then let your mind run free as you jot down answers in single entries or lists later you will choose which one is more suitable for your material. Some of the big question may not fit, and some may be more important than others, depending on the porposes of your writing. For example, if you were writing about the causes of a situation, the Why? question could be more important than the others; if you were concerned with how to do something, the How? question would predominate. If you were writing in response to a reading selection, you would confine your thinking to questions appropriately related to the content of that reading selection.

\section{METHOD}

\section{Research Design}

The method of the research was preexperimental method with one group pretest and post-test design. The class was given pre-test and post-test in which the pre-test was administered to measure prior competence of descriptive writing while the post-test was administered to measure the effect of the treatment.

\section{Population and sample}

A population is a complete set of a particular type of individual (Cramer : 2004) . The population may be all the individuals of a particular type or a more restricted part of that group. The population of interest can vary widely depending on the research question and purpose of the study. Population is all individuals from whom the data are collected. The population of this research was the whole student at Eleventh gradeof SMA MuhammadiyahRappang which were 20 students. In this research, the researcher was taking sample with census sampling technique. The number of total sample were 20 students.

\section{Instrument of the research}

To collect the data from the research, the researcher would utilize a writing test as the instrument. The students were asked to write a composition. The test was applied pre-test and post-test. The pretest was aimed at finding out the prior writing of the students' descriptive writing; while post-test was aimed at finding out the students' writing skill in descriptive composition.

\section{Procedure of collecting data}

The procedure of the research involved the following steps:

1. Pre-test was conducted treatment at the first meeting the following procedures:

a. The researcher explained what the students would going to do and distributed the writing test for the the class which took randomly, to know the students' ability in writing descriptive composition before treatment.

b. The researcher gave score to the students' result test.

2. Post-test

a. After gave the treatment, the students was given a set of writing test to found out the improvement in learning writing descriptive composition by using keyword.

b. The researcher gave score of the students' result test.

\section{Treatment}

After giving a pre-test, the researcher treatedthe group. The researcher gave the treatment for four times, each meeting runs for 80 minutes. The class group was treated by using keyword in writing descriptive composition. 
1) In the first meeting, the researcher introduced the writing description include: definition, step and what thing could be enclosed in our writing. And then, instructed the students to make writing composition about "Family" through keyword of it.

2) In the second meeting, the researcher invited the keyword of market. And then asked the students to compose those keyword based on the instruction which will be given.

3) In the third meeting, the researcher would raise the topic about farmer. The students were thought keyword and they had to compose this topic.

4) In the fourth meeting, the researcher gave the topic about village, and then would teach the keyword which talked about the topic and asked the students again to try to make a composition through the keyword based on the instruction that were given.

The researcher thought about keyword technique every meeting or each material with time allocation is 80 minutes ( $2 \times 40$ minutes). The steps in teaching writing by using keyword were:

1) The researcher gave greeting for the students.

2) The researcher checked list the name of students in class.
3) The researcher gave a motivation to each student before teaching the material.

4) The researcher introduced keyword in helping to write descriptive composition.

5) The researcher gave the keyword to each student that talk about the asking topic.

6) The researcher gave example about the material orally.

7) The researcher gave chance to each student to ask for unclearly material.

8) The researcher instructed the students to compose the topic based on the keyword.

9) The teacher asked the students to collect their writing task.

10) The teacher explained and corrected the students' probable mistake in reconstructing text.

11) The teacher in formed the students what they will do next and still give motivation in learning writing.

\section{RESULTS}

\section{Pretest and Posttest}

This section deals with the presentation of students' achievement in writing skill of descriptive composition consisted into five parts content, organization, vocabulary, language use, and mechanics and students' attitude toward the use of keyword in descriptive composition instruction.

Table 1. The percentage of the students' score of pre-test.

\begin{tabular}{lllll}
\hline \multirow{2}{*}{ NO } & Clasification & Score & Pre-test & \\
\cline { 5 - 5 } & & F & $\%$ \\
2 & Gery good & $86-100$ & & \\
3 & Fair & $56-70$ & & 40 \\
4 & Poor & $41-55$ & 8 & 60 \\
5 & Very poor & $\leq 40$ & 12 & \\
\hline TOTAL & & & $\mathbf{1 0 0}$ \\
\hline
\end{tabular}


Table 1. shows that the students' score in test result for pre-test group most of them were in fair category, $12(60 \%)$ students were classified into fair, $8(40 \%)$ students were classified into poor,. There were not any students classified very good and very poor. It means before the researcher giving treatment, the students' pre-test poor and the student's writing skill has low significantly.

Table. 2. The percentage of students' score of post-test.

\begin{tabular}{|c|c|c|c|c|}
\hline \multirow{2}{*}{ NO } & \multirow{2}{*}{ Clasification } & \multirow{2}{*}{ Score } & \multicolumn{2}{|c|}{ Post-test } \\
\hline & & & $F$ & $\%$ \\
\hline 1 & Very good & $86-100$ & & \\
\hline 2 & Good & $71-85$ & 20 & 100 \\
\hline 3 & Fair & $56-70$ & & \\
\hline 4 & Poor & $41-55$ & & \\
\hline 5 & Very poor & $\leq 40$ & & \\
\hline \multicolumn{3}{|c|}{ TOTAL } & 20 & 100 \\
\hline
\end{tabular}

shows that the students' score in test result for post-test most of them were in good category, $20(100 \%)$ students were classified into good. There were not any students classified into very good, poor and very poor. It means that there was significant difference students who taught through keyword.

\section{Mean Score and Standard Deviation}

The mean score and standard deviation of the students in pre-test and post-test are percentages as follow :

Table 3. The mean score of pre-test and post-test

\begin{tabular}{llll}
\hline No & & Pre-test & Post-test \\
\hline 1 & Mean Score & 53.60 & 77.95 \\
\hline 2 & Standard Deviation & 4.10 & 1.70 \\
\hline
\end{tabular}

who was teach by using keyword to write

Table 3. shows that the mean score of the descriptive composition was improve.

students in post-test (77.95) was greater than pre-test (53.95), it means that the students

\section{Hypothesis}

In testing hypothesis, the researcher used $p$-value formula (Paired sample test). The level of significant is set at $\alpha=0.05$.

Table 4. The p-value of the students' score of pre-test and post-test.

\begin{tabular}{ll}
\hline $\mathbf{p}$-value & Alpha $(\boldsymbol{\alpha})$ \\
\hline 0.00 & 0.05 \\
\hline
\end{tabular}

The table 4. above shows that the $p$-value was lower than alpha $(\alpha)$ value, it means

that null hypothesis was rejected and alternative hypothesis was accepted. It means that the Eleventh grade students of SMA MuhammadiyahRappang 
improve after they are taught by using keyword to write descriptive composition.

\section{Discussion}

Based on the data above, it showed that the writing skill of students pre-test and post-test has significant different, where students after applied a technique of keyword in writing descriptive composition has a higher score better than before applied keyword in writing descriptive composition.

The description of the data collected through the test as explained in the previous section showed that the students' ability in writing improved significantly. It is supported by the mean score of the students' test in post-test students. The mean score of post-test was 77.95. The data in previous section showed that applying keyword in writing descriptive composition was effective to improve students' writing descriptive composition skill. It is supported by the difference between the test mean score of post-test (77.95) was higher than the pre-test (53.95). This research data indicated that the applying keyword in writing descriptive composition was significantly improved the students' writing descriptive composition skill.

Based on the students' result obtained and stated in findings above, the researcher used t-test in inferential statistic through SPSS version 21.0 program to test the hypothesis. On statistics test result, it showed that the $p$ value is lower than alpha ( $p$-value $<\alpha)$. It means that $\mathrm{H} 1$ was accepted and $\mathrm{HO}$ was rejected. It is concluded that there was a significant difference between students in writing skill. In other words, there was an improvement on the students' writing ability after applying keyword in descriptive composition in SMA MuhammadiyahRappang.

This is also in line with Evans (2000) stated that keyword is a technique to stimulate students knowledge about the topic, thus drawing together ideas and vocabulary which is necessary for writing a successful composition, Heard and Tucker (2013) stated that keyword is the technique of listing any and all ideas that occur to the writer about a topic and. Richardc and Schmidt (2002:58) stated about keyword:

1. (in language teaching) a group activity in which learners have a free and relatively unstructured discussion on an assigned topic as a way of generatingideas. keywordoften serves preparation for another activity.

2. (in teaching writing) a form of prewriting inwhich a student or group of students write down as many thoughts aspossible on a topic without paying attention to organization, sentence structure or spelling. keywordserves to gather ideas, viewpoints, orideas related to awriting topic and issaid to help the writer produce ideas.

\section{CONCLUSION AND SUGGESTION Conclusion}

Based on the findings and discussion, students' achievement in learning writing descriptive composition through keyword was significant improve. This was indicated by the mean score they got on posttest was higher than pretest. The result of hypothesis testing showed significant score between $p$-value and alpha which is $p$-value was lower than alpha $(0.00<0.05)$. it means that the use of keyword is more effective.

\section{Suggestion}

Considering the previous conclusion, the researcher gives some suggestions as follows:

1. The teachers are recommended to apply the keyword since it is a good teaching technique and teacher-led discussions provide opportunities for schema development and enhancement. The following lines convey two recommendations. The first is addressed to the English teacher dealing with the classroom implementation of keyword in improving the students' writing (descriptive composition) achievement. The second is addressed to the foreign language-teaching researchers. 
Jurnal Edumaspul, 5 (1), Year 2021 - 277

(Andi Sadapotto, Nicodemus Bisse)

2. To apply the keyword and make it meaningful in teaching writing(descriptive composition), the role of students and also teachers is really important. Students should be fully engaged in the teaching process. Besides that, students also need modeling for teaching writing by using keyword. Therefore, teachers should familiarize students with the keyword as good technique.

\section{BIBLIOGRAPHY}

Awaluddin 2006.Improving Writing Skill of the Second Year Students of SMA Negeri1DuampanuaKabupatenPinrang by Using Spider Web.Thesis.FKIP UniversitasMuhammadiyahParepare.

Bacon, Marks. 1998. Write like Prose: Using the Secret of Writers and Journalist in Business. New York: John Willey and Sons, Inc.

Best, John W, 1977. Research in Education. New Zealand: Prentice Hall,Inc.

Bradley Christmas. 2013.The Role of Brainstorming in Improving Student Writing Performance in the EFL Classroom.Retrieved November 12, 2013

Brown, H. Douglas. 2001. Teaching by Principles: An Interactive Approach to Language Pedagogy. San Francisco: Addition Wesley Longman, Inc.

Buckingham. Louisa (2008). Development of English Academic Writing Competence by Turkish Scholars . international journal from http://ijds.org/Volume3/IJDSv3p001 -018Buckingham29.pdfByrne, Donn. 1984. English Teaching Perspective. London: Longman.

Charles Bazerman, Joseph Little, Lisa Bethel, Teri Chavkin, Danielle Faouquette, and Janet Garufis. 2005. Reference Guide to Writing Across Curricullum. West Lafayette. Indiana.

Charles F. Meyer. 2009. Introduction English Linguistic. United State of America. Cambridge University Press.
Depdiknas. 2006. Kurikulum 2006: Standar Kompetensi SMP. Jakarta: Dharma Bakti.

Dr. Catherine Dawson. 2002. Introduction to Research Method.United Kindom. Howtobook.

Duncan Cramer and Dennis Howitt. 2004. The SAGE Dictionary of Statistic. London. SAGE Publication

Fatima.sadaf (2012). Teaching Report Writing Skills through Communicative Activities. International journal from http://www.researchgate.net/profil e/Sadaf Fatima5/publication/25919 7157.pdf

Gay, L. R., et al. 2006. Educational Research Competencies for Analysis and Applications: Eight Edition. Columbus Ohio. Pearson Merril Prentice Hall.

Ghaith, Ghazi. 2002. Writing. Retrieved March $2^{\text {nd }}, 2013$, from

Gunersel \& simpson(2009). improvement in writing and reviewing skills and calibrated peer reviewTM. International journal from http://digitalcommons.georgiasouther n.edu/cgi/viewcontent.cgi?article $=11$ 81\&context

Harmer, Jeremy. 1991. The Practical of English Language Teaching (New Edition). New York: Longman Publishing.. 1993. The Practical of English Language Teaching. New York: Longman Inc.

http://childparenting.about.com/od/schoolle arning/a/4-types-of-writingstyles.htm

http://kelompok2andriaditia.blogspot.com/20 14/03/writing-skill-bab-1pendahuluan-1.html http://www.edwarddebono.com

http://www.memory-improvementtips.com/keywordmethod.html\#sthash.8VzdNvGk.dpu $\underline{f}$ http://www.mindtools.comhttp:// www.edwarddebono.com

http://www.pbs.org/parents/education/learni ng-disabilities/types/writing/theimportance-of-writing/ 
http://www.pengertianahli.com/2014/01/pen gertian-menulis-dan-tujuan menulis.html http://www.thefreedictionary.com/ writing.

http://www.time4writing.com/writingresources/writing-process/

https://zhaminang.wordpress.com/2013/05/1 7/definisi-menulis-menurut-paraahli/

Hughes, Arthur. 2008. Testing for Language Learners, UK: Cambridge University.

Iryani. 1998. The Ability of the Fifth Semester Students of English Department of FBS IKIP Ujungpandang to compose Descriptive Pargraph Using Familiar Pictures. Thesis FBS UNM.

Jack C. Richard, Willy A. Renandia. 2002. Methodology in Language teaching. Cambridge University Press.

Jack C. Richards and Richard Schmidt. 2002. Longman Dictionary of Language Teaching and Applied Third Edition. New york. Pearson Education Limited.

James Heard, M. Ed. And Ted Tucker, M. Ed .2013. Advanced Writing.

Javed, Juan,\& Nazli. (2013). A Study of Students' Assessment in Writing Skill of the English Language. Internation journal from http://files.eric.ed.gov/fulltext/ED54 4075.pdf

Judith F. Oslon. 2009. Writing Skill Success.New York. Learning Express.

Marrie allen and paul procter. 2008. Cambridge Advanced Learner's Dictionary Third Edition. Cambridge University Press.

Masni Santung. 2011. Improving Writing Skill By Using Writing Process Approach At The Second Grade (Tkj Department) Students of Smk Nasional Makassar.UMM

Muhammad Nahdi. 2011. Improving Students' Writing Ability by Using Peer Editing Technique (A Classroom Action Research at the Third Semester Students of English Study Program of STKIP HAMZANWADI SELONG in Academic Year of 2010/2011).
Philis Creme and Mary R. Lea. 2003. Writing at University. Maidenhead, Newbury. Open University Press.

Prof. Drs. Sutrisno Hadi. 1987. Statistik Jilid 2. Yogyakarta. Fakultas Psikologi UGM Yogyakarta

Rao Z. (2007) Training in Brainstorming and Developing Writing Skills, in ELT Journal 2007 61(2). Oxford University Press. Retrieved November 12, 2013.

Simard, Jean. 1997. The Writing Process in a Multimedia Environment. Retrieved March 2 2 $2^{\text {nd }} \quad 2013$, from http://technologysource.org/article/.

Sintawati. 2012. Pembelajaran Menulis Paragraf Narasi Dengan Menggunakan Metode Clustering Pada Siswa Smpn 1 Tanggeung Kab.Cianjur. STKIP Siliwangi Bandung.

Sugiyono. 2007. Metode Penelitian Pendidikan (Pendekatan Kuantitatif, Kualitatif, dan R\&D). Bandung: Alfabeta.

Suyatinah.

2013.PeningkatanKeefektifanPembel ajaranMenulis Di Kelas Ii SekolahDasar. PGSD FIP UniversitasNegeri Yogyakarta.

Theresa Clementon. 2005. Reading and Writing Skill. NY. Oxford University Press.

Thomas S. Kane. 2000. Essential Guide to Write. New york. Berkley Book.

Thulis Dawes. 2009. Learning Write With Purpose. Learning Write With Purpose. NY. The Guilford Press.

Virginia Evans. 2000. Successful Writing. Liberty House, New Greenham Park, Newbury, Berkshire. Express Publishing.

Wells, Gardin. 1993. Writing: the Hobby about that Pays. Singapore. EPB Publisher Ptc. Ltd.

Zuzanne Bratcher and lynda Ryan. 2004. Evaluating Childrens's Writing. Lawrence Erlbaum Associates, Publishers Mahwah, New Jersey London 